\title{
Public Service Innovation in Issuance of Building Permits in Sidoarjo Regency
}

\author{
Malihatul Fuadah ${ }^{1}$, Ismi Dwi Astuti Nurhaeni' ${ }^{2}$, Sri Yuliani ${ }^{3}$ \\ ${ }^{1}$ Ilmu Administrasi Negara, Universitas Sebelas Maret Surakarta, Indonesia \\ ${ }^{2}$ Ilmu Administrasi Negara, Universitas Sebelas Maret Surakarta, Indonesia \\ 3Ilmu Administrasi Negara, Universitas Sebelas Maret Surakarta, Indonesia \\ (email: malihatulfuadah23@student.uns.ac.id)
}

\begin{abstract}
The innovation of public services provided by the Investment and One Stop Service Office provides many benefits for people who use the services and services of the relevant agencies. This innovation also helps a lot in terms of issuing building permits which are one of the most needed public services by the community, where in its implementation requires accuracy and speed in managing and issuing building permits so that buildings used for business get legal. The purpose of the launch of SIPPADU has been stated in the Regulation of the Regent of Sidoarjo Number 8 of 2017 concerning the Application of Information Technology in Integrated Services. The type of research used is descriptive research with a qualitative approach. The focus in this research is how public service innovations in overcoming delays in the issuance of IMB files through the Integrated Licensing Service Information System program by the Investment Office and One Stop Integrated Service of Sidoarjo Regency which includes forms of innovation, processes and cycles of innovation as well as the diffusion of innovations at the Investment Office. and One Stop Services in Sidoarjo Regency. Based on the results of the research above, it can be concluded that technology-based innovations made by the Office of Investment and One Stop Integrated Services, namely the SIPPADU application, have helped the operation of licensing services at the agency. the service is to upgrade this SIPPADU innovation in the future so that things don't happen such as unstable networks, applications or websites that can't be accessed because the server is down. As well as providing more direction to existing Human Resources to understand more about SIPPADU. Suggestions for the public is to add more information about the SIPPADU application which can be accessed through the website of the Sidoarjo Regency Investment and One Stop Integrated Service website.
\end{abstract}

\section{Keywords:}

Innovation; Public Service; SIPPADU

\section{Introduction}

Utilization of Information Technology in the government sector is marked by the development of Electronic Government (E-Gov). Over time, the government wants to provide 
services that are effective, timely and efficient. The government is increasingly developing from paper-based services to electronic-based services. This technology can serve multiple purposes: better delivery of government services to citizens, increased interaction with business and industry, community empowerment through access to information. The resulting benefits could be less corruption, increased transparency, greater convenience, revenue growth and/or cost reduction. The advantages of implementing E-Gov such as increasing the efficiency of government agencies in data processing, improving services through a better understanding of user requirements, sharing of info and ideas among all government agencies and departments to build a data base and help the government's economic policy objectives.

In Indonesia, the implementation of E-Gov began officially with the issuance of the Instruction of the President of the Republic of Indonesia Number 3 of 2003 concerning National Policy and Strategy for E-Government Development. Gathering several previous studies, Mesnan Silalahi et al concluded that there was little success in the level of implementation of E-Gov in the world, including in Indonesia. He also mentioned a number of challenges such as Human Resources, Infrastructure, Community Literacy, Leader Commitment, and Culture.

The current low quality of service in Indonesia encourages the government to immediately improve the quality of its services. This is in accordance with the explanation according to Surjadi (2009:7) regarding the implementation of public services is an objective condition which shows that the implementation of public services is still faced with a government system that is not yet effective and efficient, and the quality of human resources and state apparatus is inadequate. several service areas that become community report data. The data is detailed in the following table:

Table 1.

Community Report Data Based on Reported Agencies Year 2017

\begin{tabular}{llc}
\hline No & Reported Agency & Number of Reports \\
\hline 1. & Regional Government & 681 \\
2. & Police & 212 \\
3. & National Land Agency & 184 \\
4. & Government Agencies & 155 \\
5. & BUMNBUMD & 130 \\
6. & State Education Institutions & 62 \\
\hline
\end{tabular}




\begin{tabular}{|c|c|c|}
\hline No & Reported Agency & Number of Reports \\
\hline 7. & Banking & 53 \\
\hline 8. & Judicary & 39 \\
\hline 9. & Others & 25 \\
\hline 10. & State Commision & 23 \\
\hline 11. & Prosecutor & 19 \\
\hline 12. & State College & 19 \\
\hline 13. & Government Hospital & 15 \\
\hline 14. & $\begin{array}{l}\text { Non-Ministterial } \\
\text { Institutions }\end{array}$ & 11 \\
\hline 15. & Indonesian National Army & 4 \\
\hline 16. & People's Representative & 3 \\
\hline 17. & Private Education Institutions & 2 \\
\hline
\end{tabular}

Source: Open Access Data Ombudsman RI, 2017

As the first most reported agency, the Regional Government is one of the agencies that are considered to have poor public services. Therefore, the Regional Government seeks to improve the quality of public services through a good public service, one of which is carried out by the Regional Government of Sidoarjo Regency through The Office of Investment and One Stop Integrated Services (DPMPTSP) of Sidoarjo Regency.

However, in 2015 the department experienced delays in the issuance of documents in the service of Building Permits (IMB), this can be seen in the following table:

Table 2.

\section{Recapitulation of IMB Service Process}

\begin{tabular}{lllll}
\hline No & Year & Total & On Time & Late \\
\hline 1. & 2015 & 1012 & 1008 & 4 \\
2. & 2016 & 1267 & 1267 & - \\
3. & 2017 & 506 & 506 & - \\
\hline
\end{tabular}

Source: Data from the Office of Investment and One Stop Services in 2017

If we look at the data in the table, the delay in the issuance of files in the service of Building Permits (IMB) occurred in 2015. This coincided with before the manual or offline service system was replaced to an online service system through the SIPPADU application in 2017 in accordance with the Regulation Sidoarjo Regent Number 8 of 2017 concerning the Application of Information Technology in One-Stop Integrated Services. When viewed in 2017 where licensing services have begun to switch to using an online service system, the DPMPTSP of Sidoarjo Regency has not experienced delays.

In accordance with Sidoarjo Regent Regulation No. 8 of 2017 concerning Application of Information Technology in One Stop Services, it shows that the Sidoarjo Regency 
Investment and One Stop Integrated Service (DPMPTSP) actually implements a system based on the Integrated Licensing Service Information System (SIPPADU). ). SIPPADU is a public service in the form of electronic government that integrates all types of licensing through a mobile application.

The innovation of public services provided by the Investment and One Stop Service Office provides many benefits for people who use the services and services of the relevant agencies. This innovation also helps a lot in terms of issuing building permits which are one of the public services most needed by the community, where in its implementation requires accuracy and speed of processing and issuing building permit files so that buildings used for business get legality. Timeliness in publishing licensing carried out by the Office of Investment and One Stop Integrated Services is one proof that the innovation provided by the agency is very good. As well as being proven by getting a Category A Role Model Award for Public Service Delivery from the Deputy for Public Services of the Ministry of PAN \& RB in February 2017.

From the above, it is interesting to study "how is the innovation of public services in overcoming delays in the issuance of IMB files through SIPPADU?". To ensure mission effectiveness, organizations should seek to improve their operations, which include service innovation and citizens. Service innovation is the concrete way an organization applies all other innovations, from mission innovation to partner innovation, or to specific benefits experienced by its clients. Enhancement of human dignity, sustainability, or national stability, other offerings are tangible results of public service innovation. Public sector organizations can innovate by offering existing or new services to new users and vice versa to further facilitate the mandate represented by the organization's mission statement or promised by a public policy. Service innovation is the introduction and delivery of new services to achieve organizational goals.

According to Muluk (2008:42) innovation in the public sector is carried out in order to increase efficiency and reduce costs considering that basically public sector organizations always face resource scarcity and budget constraints. Innovation can also be used to improve service quality and its impact on the community, especially to overcome previous policies that did not show satisfactory results. There are five kinds of innovation attributes according to Rogers cited by Suwarno (2008:17), including: a) Relative Advantage or relative advantage; b) 
Compatibility or suitability; c) Complexity or complexity; d) Triability or leadership is tried; and e) Observability or ease of observation.

According to Mulgan \& Alburry quoted by Muluk (2008:44) states there are five typologies in the innovation process, namely: a) Product or service innovation; b) Service process innovation; c) Service method innovation; d) Policy innovation; and e) System innovation. The diffusion of innovation consists of 2 words, namely diffusion and innovation. Rogers 1995 (in Sciffman and Kanuk, 2010) defines diffusion as the process by which an innovation is communicated through certain channels over a period of time among the members of a social system. According to Suwarno (2008:13) there are two types of diffusion models, namely the internal influence diffusion model and the external influence diffusion model.

The innovation development process according to Suwarno (2008:19) goes through the stages of Needs or problems, Basic and Applicative Research, Development, Commercialization, Diffusion and Adoption, and Consequences. According to Muluk (2008:49) there are several critical factors in the development of innovation, including Innovation Leadership Development, Innovation Culture Development, Employee Development, Team and Partnership Development, Innovation Performance Development, and Innovation Network Development.

According to Ancok (2012:58) there are three supporting innovations, namely as follows: Human capital; Leadership capital; and Capital organizational structure. Meanwhile, according to Mulgan and Albury in Noor (2013: 27) there are eight barriers to innovation in the public sector, namely as follows: Reluctance to close failed programs; Excessive reliance on high-performance displays as a source of innovation; Technology available, but impeding culture or organization; There are no rewards or incentives for innovating or adopting innovations; Do not dare to take risks; Short term budgeting and planning; Administrative pressures and barriers; and Culture

According to Keban quoted by Jumara (2010:16) states that in the context of public services, the emphasis is more on how elements of public administration such as policy making, organizational design, and management processes are utilized to make the delivery of public services successful, where the government is the provider who is given responsibility. 
There are several forms of innovation in various fields, including Product Innovation, Educational Innovation, Public Service Innovation, Technological Innovation, and Cultural Innovation. The Innovation process and cycle is also carried out in 3 stages, namely the first, encouraging each service unit to produce breakthroughs. The second stage is to develop these innovations on a national scale, and the last stage is to institutionalize the best innovations so that they are sustainable. The theory used in this research is the theory of diffusion of innovation by Everett M. Rogers. Diffusion of innovation has the meaning of a special type of communication related to the dissemination of messages or information as a new idea of innovation. According to Everett M. Rogers in his book entitled "Diffusion of Innovation" (2003:4-5) defines that, diffusion is the process of delivering innovation through certain channels from time to time to members of the social system. Rogers said that there are four main elements or elements in the diffusion of innovation, namely a) innovation; b) communication channel c) timeframe; d) social system.

With the many industries that are starting to develop in the Sidoarjo Regency area, it makes more and more business or industrial buildings to be established in various areas in Sidoarjo Regency. With the construction of buildings for the purposes of industrial buildings and business buildings, the existence of a Building Permit or IMB is certainly very necessary for business owners as proof of legal building ownership. In providing licensing services quickly and accurately, the Regional Government of Sidoarjo Regency launched an Integrated Service Information System or commonly known as SIPPADU in accordance with Sidoarjo Regent Regulation Number 8 of 2017 concerning Application of Information Technology in One-Stop Integrated Services, the implementation of which is carried out by the Investment and Investment Agency. One Stop Service (DPMPTSP) Sidoarjo Regency.

This Integrated Service Information System (SIPPADU) is an application made by the Sidoarjo Regency Government which is then implemented by the Sidoarjo Regency Investment and One Stop Integrated Service Office. This SIPPADU application can be downloaded through the application install application on each mobile. In addition to being in the form of an application, SIPPADU is also in the form of a website where this website can be accessed by the entire community in order to obtain services related to licensing and investment. To access this SIPPADU website, users only need to type 
sippadu.dpmptsp.sidoarjokab.go.id on the page Google users, both via PC and Android users.

The purpose of the launch of SIPPADU has been stated in the Regulation of the Regent of Sidoarjo Number 8 of 2017 concerning the Application of Information Technology in Integrated Services. This objective lies in Article 3, which states that the purpose of SIPPADU is to provide easy, fast, accurate and affordable licensing and non-licensing services as well as transparent and accountable licensing services.

\section{Methods}

The type of research used is descriptive research with a qualitative approach. Faisal (2003:20) states that descriptive research is a research that is intended for exploration and clarification of a phenomenon or social reality, by describing a number of variables relating to the problem and unit under study. The focus of this research is how public service innovations in the issuance of IMB files through the Integrated Licensing Service Information System program by the Sidoarjo Regency Investment and One Stop Integrated Service (Abdullah, 2003) which includes the form of innovation, process and cycle of innovation as well as the diffusion of innovation at the Investment Office and Integrated Services One. Sidoarjo Regency door.

The research location chosen by the author is the Office of the Investment and One Stop Service Office of Sidoarjo Regency. Then the research sites include: the Office of Investment and One Stop Services in Sidoarjo Regency and the community who use DPMPTSP services in Sidoarjo Regency, especially SIPPADU users. Data sources are divided into three, namely: (1) Informants include: Licensing Section of the Sidoarjo Regency Investment and One Stop Integrated Service (DPMPTSP), Service, Information and Complaints Section of the Sidoarjo Regency Investment and One Stop Integrated Service (DPMPTSP), and users of the Integrated Service Information System (SIPPADU), both users through the SIPPADU application on the user's android and users through the SIPPADU website. (2) documents, (3) events. The types of data consist of primary data sourced from: Licensing Section of DPMPSTP, Service Section, Information and Complaints of DPMPTSP, as well as users of SIPPADU services and secondary data obtained from documents, photos, data complications, reports, records at the Investment and Service Office. One Stop Sidoarjo 
Regency. Data was collected through observation, interviews and documentation. The research instruments are the researchers themselves, interview guidelines, field notes, and supporting tools. Data analysis uses data analysis model Miles, Huberman and Saldana, (2014:8) which consists of four stages, namely: data collection, data condensation, data presentation, and conclusions.

\section{Result and Disscusion}

SIPPADU is a public service in the form of electronic government or known as E-Gov which integrates all types of licensing through mobile applications and through the website. SIPPADU implements one package licensing service. This is an innovation of the Sidoarjo Regency DPMPTSP to combine the procedures and stages of obtaining permits into one integrated process. This is done to simplify the licensing process, reduce queues, reduce file build-up, reduce paper usage, cut time usage, and the absence of brokering practices due to reduced intensity of face-to-face meetings between applicants and service personnel, thereby creating increased performance and accelerated service to the community.

The implementation of the Integrated Licensing Service Information System (SIPPADU) makes it easier for applicants not to have to go to the Sidoarjo Regency Investment and One Stop Integrated Service Office because the file processing is done through the SIPPADU website.

The applicant is required to upload the application document online on the website sippadu.dpmptsp.sidoarjokab.go.id, after that the customer service officer who is an officer of the Investment and One Stop Service Office of Sidoarjo Regency checks the completeness of the uploaded document. by the applicant online, then CS gives it to the Head of Sie for verification and a field review if needed. After the verification is complete, the Head of Section then makes and provides the calculation of the Regional Levies Determination Letter (SKRD) after that makes the Minutes of Review (BAP) and clicks on the initials of the draft SK.

After clicking on the initials of the draft SK from the Head of Section, then it is submitted to the Head of the Division or Head of Division for validation and clicks on the draft SK and the Regional Retribution Determination Letter (SKRD) is determined by the Head of the Division. After that, it is given to the Head of Service for approval and approval of the Decree. After that, it is submitted to Customer Service so that the validated SK is 
submitted to the applicant. After the applicant receives the SK that has been validated, the applicant goes to the Bank Jatim Office to make a retribution payment.

In this study, the innovation made by the One Stop Service and Investment Service through the SIPPADU innovation is a Public Service Innovation. Because this SIPPADU innovation is a public service that does not require direct face-to-face meetings between officers and the public who need services, but can be done online through a network. The process and cycle of public service innovation carried out by the Investment Service and One Stop Integrated Service of Sidoarjo Regency is carried out in 3 stages according to the process and cycle of public service innovation, namely in the first stage the Regional Government encourages DPMPTSP to give birth to new breakthroughs. The second stage, DPMPTSP begins to develop public service innovations in the form of SIPPADU on a national scale, and the last stage is the efforts of the relevant agencies in institutionalizing this SIPPADU innovation so that it can continue to be sustainable so that it continues to provide benefits and convenience for its users.

The existence of the SIPPADU innovation made by the Investment and One Stop Service Office of Sidoarjo Regency is very helpful for the running of public services at the agency. One of them is the absence of delays in the issuance of the building permit file so that it does not hinder the running of public services provided to the community. However, the agency also encountered obstacles regarding servers that were also down because they were used by many people as users to get services quickly and efficiently. And there are still Human Resources who have not mastered the existing Information Technology, so that it can hinder the operation of the Integrated Licensing Service Information System (SIPPADU).

\section{Conclusion}

Based on the results of the research above, it can be concluded that technology-based innovations made by the Office of Investment and One Stop Integrated Services, namely the SIPPADU application, have helped the licensing service run at the agency. It is proven by the absence of delays in the issuance of the IMB file when the new SIPPADU is run. This innovation also provides many benefits, such as reducing queues, reducing file accumulation, reducing paper use, cutting time usage, and the absence of brokering practices due to the reduced intensity of face-to-face meetings between applicants and the official apparatus, 
resulting in increased performance and accelerated service to the community. The innovation made by the Office of Investment and One Stop Integrated Services through the SIPPADU innovation is a Public Service Innovation. Because this SIPPADU innovation is a public service that does not require direct face-to-face meetings between officers and the public who need services, but can be done online through a network. The process and cycle of public service innovation carried out by the Investment Service and One Stop Integrated Service of Sidoarjo Regency is carried out in 3 stages according to the process and cycle of public service innovation, namely in the first stage the Regional Government encourages DPMPTSP to give birth to new breakthroughs. The second stage, DPMPTSP begins to develop public service innovations in the form of SIPPADU on a national scale, and the last stage is the efforts of the relevant agencies in institutionalizing this SIPPADU innovation so that it can continue to be sustainable so that it continues to provide benefits and convenience for its users.

SIPPADU makes it easy for business actors who want to have the legality of their buildings. However, because SIPPADU is a technology-based application, SIPPADU can also be hampered by signals and so on.

The advice given by the author to the office is to further upgrade this SIPPADU innovation in the future so that things don't happen such as unstable networks, applications or websites that cannot be accessed because the server is down. As well as providing more direction to existing Human Resources to understand more about SIPPADU. Suggestions for the public is to add more information about the SIPPADU application which can be accessed through the website of the Sidoarjo Regency Investment and One Stop Integrated Service website.

\section{References}

Data from the Investment and One Stop Service Office of Sidoarjo Regency

Abdullah, F. (2003). Dasar-Dasar Manajemen Keuangan. Malang: UMM Press.

Ancok, D. (2012). Psikologi Kepemimpinan dan Inovasi . Jakarta: Erlangga.

Dwiyanto, A. (2006). Realizing Good Governance Through Public Services. Yogyakarta: Gadjah Mada University.

Hidayat, A. (2012). Definition and Explanation of Quantitative Research. Definition of Quantitative Research, 53. 
Keban. (2008). Enam Dimensi Strategis Administrasi Publik. Yogyakarta: Gava Media.

Kurniawan. (2016). Performance Evaluation of the One Stop Integrated Service at the Integrated Licensing and Investment Coordination Midwife of Nunukan Regency. Public Service , 20-22.

Muluk, K. (2008). Knowledge Management Kunci Sukses Inovasi Pemerintahan Daerah Malang. Malang: Bayu Media Publisher.

Surjadi. (2009). Pengembangan Kinerja Pelayanan Publik. Bandung: Refika Aditama.

Suwarno. (2008). Inovasi di Sektor Publik. Jakarta: STIA-LAN.

Tangkilisan. (2015). Public Management. Jakarta: Grasindo.

Ulfatiyana, M. (2020). Diffusion of Service Innovations for the Free School Transport Program in Madiun City. Journal of Public Administration , 4. 